\title{
O CARÁTER HISTÓRICO-SOCIAL DO CONHECIMENTO NO PENSAMENTO DE MARX
}

\author{
Reginaldo Aliçandro Bordin ${ }^{I}$
}

\begin{abstract}
Resumo: Este texto tem por objetivo discutir a teoria do conhecimento em Marx e em Engels, além de pontuar os estudos que realizaram sobre a ciência. Esses pensadores do século XIX não se destacaram por elaborar reflexóes filosóficas sobre o tema, tal como os modernos fizeram; para compreender o momento histórico deles, caracterizado pela produção capitalista, as preocupaçôes orientavam-se para revisar as filosofias idealistas, considerando-as ideológicas e insuficientes para pensar o que entendiam por realidade material, social. Em contraposiçấo, elaboraram um novo pressuposto teórico pelo qual procuravam explicitar a articulação entre as forças produtivas, concebendo-as como base sob as quais se engendram as relaçóes sociais e as ideias a elas correspondentes, bem como as lutas históricas travadas no interior da mesma sociedade. Compreenderam que o conhecimento e a ciência estáo articulados com as bases materiais da produçấo e que cabe a eles explicar as relaçóes. Esse modo de entender a sociedade de seu tempo mostra-se original, o que justifica estudos que tendem a buscar neles referências teóricas para explicitar as contradiçôes atuais.
\end{abstract}

Palavras-Chave: Ciência. Conhecimento. Marxismo.

\section{INTRODUÇÃo}

Neste ensaio, o que se propóe é uma análise do pensamento marxiano referente à ciência e suas relaçóes com a sociedade. Ainda que Marx e Engels não tivessem elaborado uma teoria do conhecimento, tal como a pretendida pela filosofia antiga e moderna, nem formulado uma teoria epistemológica segundo o molde dos filósofos contemporâneos, neles se vislumbra uma questão relevante e atual: não se ocupavam com as faculdades do conhecimento, mas com a origem social das ideias, do pensamento e das ciências. Ao delimitar o campo de análise para os aspectos históricos e sociais do pensamento, Marx e Engels esboçaram um modelo teórico em que pretendem contestar as posiçóes filosóficas e sociológicas até então conhecidas, a exemplo do idealismo hegeliano e do positivismo de Comte.

A revisão dos princípios teóricos que caracterizaram o século XIX resultava do empenho em compreender a produçáo capitalista que se

\footnotetext{
${ }^{1}$ Mestre e doutor em Educação, UEM, Maringá -Pr. É professor do Programa de Pós-Graduaçâo em Gestâo do Conhecimento nas Organizaçôes, da UNicesumar e bolsista produtividade e pesquisador do Instituto Cesumar de Ciência, Tecnologia e Inovação (ICETI). Também é professor de Filosofia na Pontifícia Universidade Católica do Paraná.E-mail: r.a.bordin@uol.com.br
}

http://dx.doi.org/10.1590/S0101-31732017000300009 
estabelecia e as lutas trabalhistas que abalaram especialmente a França, sobretudo, nos anos de 1848. Em face desse momento, Marx, como teórico e homem de ação, instaurou as bases de uma teoria sobre a sociedade burguesa que, nucleada numa ontologia social fundada no trabalho, permanece no centro das polêmicas relativas à natureza, à estrutura e à dinâmica da sociedade em que vivemos (PAULO NETTO, 2012). Gestada e proposta no século XIX como pensamento crítico capaz de fecundar processos revolucionários, mas contestada nos séculos seguintes, a obra de Marx e Engels não se limitou aos princípios da militância ou da análise econômica da sociedade burguesa: outras questóes compuseram o quadro geral do pensamento marxiano, entre os quais o que constitui o objetivo principal deste ensaio: refletir sobre a origem social da ciência e do conhecimento. Pensar sobre esses temas é, também, problematizar o que é o conhecimento e como ele foi apropriado para fins econômicos e náo às necessidades humanas.

Por isso, o percurso teórico metodológico proposto parte da investigação das principais obras onde os autores anunciam a preocupaçáo com o assunto. As posiçóes de Marx e Engels sobre os referidos temas náo se encontram explicitadas, de maneira sistemática, em um único texto. Nos Manuscritos Econômico-Filosóficos ou Manuscritos de Paris, de 1848, Marx e Engels examinam as ciências naturais como aquelas que contrapuseram a tarefa especulativa e subjetivista da filosofia. No Capital, obra de maturidade, Marx teorizou acerca da apropriação das ciências e do conhecimento pelo capital, e, na Carta de Marx a Engels em 07 de Dezembro de 1867, o autor assinala a importância de Darwin para o entendimento da história. Por sua vez, Engels (s/d), quem mais se dedicou a essa temática, anunciou na Introdução à Dialética da natureza, os avanços das modernas ciências naturais, avaliando o impacto delas para a humanidade e apontando as transformaçóes que o conhecimento desde os gregos alcançara.

O que está subjacente às declaraçóes de Marx e Engels, ainda que esparsas em suas obras, implica o fato de que se ocuparam em pensar a ciência (de modo particular) e o conhecimento (de modo geral) enquanto possibilidade de superação das contradições sociais, considerando o conjunto de suas articulaçóes. Desse modo, concebem a ciência como uma ação que pretende revelar a dinâmica do mundo real, a fim de superá-lo. Se a técnica diz respeito à aplicação do conhecimento na produção econômica (e da vida humana), a tarefa da ciência consiste em fornecer os elementos teóricos e críticos para superar as contradiçóes históricas e sociais. 
Em face dessa perspectiva, o pensamento de Marx e Engels sobre a ciência e o conhecimento é relevante e atual, porque eles teorizaram a relaçáo entre o conhecimento e a realidade objetiva. Nesse caso, compreenderam que o objeto do conhecimento é a realidade construída, historicamente, pelo próprio sujeito. Repensá-lo a partir do materialismo histórico, por fim, significa estabelecer a crítica às configuraçôes atuais da ciência e do saber entendidas como mercadorias.

\section{CIÊNCIA E SOCIEDADE: A HISTORICIDADE DO CONHECIMENTO}

No Prometeu Acorrentado, Ésquilo relata o roubo do fogo de Zeus por Prometeu, anunciando para os gregos um feito fundamental: na compreensão do poeta trágico, o homem passou a ser assistido e comandado pela astúcia da razão, levando-o a romper com as crenças mitológicas e com a dependência dele em relação aos deuses. A obediência dos homens às forças divinas, movida pelo temor, tinha como pressuposto a satisfação das necessidades, garantidas pelos louvores dos homens prestados às suas divindades. No mito, Prometeu é visto como rebelde, porque enfrenta Zeus e retira dele a dependência que os homens tinham. Ao receberem o fogo, símbolo do conhecimento e da técnica que dele resultavam, os homens tornaram-se capazes de produzir seus instrumentos e a arte que lhes garantiriam a subsistência. Porém, a rebelião de Prometeu sugere um aspecto importante, quando se considera o pensamento de Marx: a rebeldia instala-se contra a produção capitalista e a filosofia idealista, ao mesmo tempo em que anuncia a emancipação humana, possibilitada pela compreensão dos operários como força revolucionária, porque estão atrelados a uma ordem produtiva, a qual reproduz ideologicamente a dependência deles em relação aos meios produtivos.

A referência de Marx (2004) ao mito prometeico, no Prefácio da tese de doutorado em filosofia, $A$ diferença entre as filosofias da natureza em Demócrito e Epicuro, de 1841, parece indicar que seu autor pretendia combater da história da filosofia uma concepção de mundo especulativa e o vínculo que ele entendeu que ela havia estabelecido com a teologia. Ao voltar-se para a filosofia helênica, particularmente, a de Demócrito e Epicuro, Marx insurge-se contra as concepçóes idealistas, porque expressam uma consciência que se volta para o céu (mundo das ideias) e não para a terra (vida concreta dos homens). Além do mais, o mito de Prometeu, que enseja o desenvolvimento da civilização, é venerado como o deus da produçáo e do artesanato e, em Marx, ele assume 
uma condição nova: para Hinkelammert, Marx, quando se refere a Prometeu, confere a ele a condição de portador de uma filosofia que não deve pronunciar ódio, mas sentenças, isto é, a condição de discernir os diversos aspectos de uma realidade, que não é divina. A luta dos homens não deve ser travada contra os céus, mas direcionada à terra e aos seus deuses, o mercado e o Estado, tomados como falsas divindades (HINKELAMMERT, 2007).

Nada, portanto, mais humano do que combater as forças que subjugam os homens, quando se têm em conta as novas lutas travadas no desenrolar da história, em suas etapas de transformação. Ao recuperar o mito prometeico, Marx parece ter encontrado o fio de Ariadne que iria percorrer até as suas obras de maturidade, qual seja: a exigência de uma postura teórica que levasse à desmitificaçáo do mundo material. Ainda que Althusser, em seu livro A Favor de $\operatorname{Marx}^{2}$ (1967), houvesse reconhecido uma diferença substancial entre os escritos marxianos, tal interpretação é contestada, sobretudo, por Thompson (1981), o qual acusa Althusser de fazer leituras empiristas e estruturalistas de Marx, que conduziriam a erros na interpretação dos conceitos fundamentais desse pensador, entre os quais história e ideologia. É possível, segundo Thompson, identificar neles uma unidade teórica que percorre o conjunto da obra. Para o entendimento de um sistema produtivo deificado, a contestação dos matizes teóricos de seu tempo tinha como pano de fundo a articulação das ideias filosóficas com as bases materiais da produção. Além disso, ao optar pelo que considerava a filosofia materialista de Demócrito e Epicuro, Marx sugere que estava à procura de uma nova epistemologia, a qual pudesse fundamentar seu pensamento e, portanto, quase como um Prometeu, insurge-se contra as teorias filosóficas até então reinantes.

Assim, se tomarmos a divisão artificial de pensamento marxiano elaborada por Althusser, é possível traçar uma linha de demarcação que pressupóe dois momentos fundamentais. No primeiro, chamado de "Escritos de Juventude", Marx mostra-se comprometido em combater o subjetivismo filosófico e político e, por extensão, validar a teoria marxiana em favor da luta de classes, que considerava como revolucionária. Para isso, tinha que enfrentar

\footnotetext{
2 Althusser assevera haver um "corte epistemológico" nos textos de Marx. Nos primeiros escritos, identificou no autor de o Capital uma preocupaçáo maior com as filosofias contemplativas e com a ideologia burguesa, revelando-se próximo a Hegel; nos trabalhos posteriores a 1848, sua preocupação volta-se para a economia e a política. Essa posiçáo foi duramente criticada por Thompson, no livro dedicado a essa discussão, a Miséria da Teoria (1981, p. 19), em que o autor também acusa Althusser de fazer uma confusão entre o empirismo (positivismo filosófico e tudo o que lhe é afim) e o modo empírico da prática intelectual.
} 
a dialética hegeliana e estabelecer a diferença dela com a dialética materialista. Nos Manuscritos Econômicos e Filosóficos, Marx (2010)denuncia o aparato filosófico (o idealismo hegeliano e o positivismo de Comte), porque concebe o conhecimento com base em categorias abstratas. A dialética hegeliana, para ele, era positiva, na medida em que pressupunha compreender o movimento com base na luta dos contrários, mas, para Marx, Hegel terminava sua filosofia no "espírito absoluto", isto é, na compreensão da razão enquanto fundamento da realidade.

Ora, o que Marx denunciava eram os usos ideológicos que atribuía à filosofia, por pensar que ela não mais possibilitava compreender o movimento real, concreto da história. A crítica que Marx também faz a Feuerbach (18041872), em suas Teses sobre Feuerbach (1984), indicava que a filosofia havia se transformado em "autoalienaçáo" religiosa, em justificaçáo ideológica, o que significava ter-se evadido da história material dos homens. Segundo Marx, na quinta tese ${ }^{3}$, Feuerbach não captou a sensibilidade como atividade prática, humana e sensível, erro que também aponta em Hegel. ${ }^{4}$ Em oposição a esses autores, Caio Prado Júnior (2001) afirma que a novidade de Marx reside no fato de que não propôs inventar um esquema introspectivamente revelado e especulativamente desenvolvido. Ele procurou compreender a maneira pela qual o conhecimento era efetivamente elaborado nos pensadores, filósofos e cientistas que o precederam.

$\mathrm{Na}$ tentativa de romper com a tradição idealista, que concebia o conhecimento desvinculado das bases materiais, Engels (1987), na Carta a Konrad Schmidt, de 27 de outubro de 1890, afirma que, até então, as esferas ideológicas pairavam no ar (a religião, a filosofia) e que elas seriam representaçôes falsas da natureza, do próprio ser humano, dos espíritos etc. $\mathrm{O}$ que eles entendiam era o fato de que o conhecimento e as ideologias estavam consubstanciados com os modos de produção, assim como a religião, a família, o direito e a ciência e, por isso, foram tidos como condiçóes ideológicas que legitimavam o modelo de produção a que essas "formas particulares" estavam circunscritas (MARX, 2010, p. 106).

\footnotetext{
${ }^{3}$ Feuerbach, não contente com as origens do pensamento abstrato, quer o conhecimento sensível (Anschauung), porém, não toma o mundo sensível como atividade humana sensível e prática (MARX; ENGELS, 1984, p. 109).

${ }^{4}$ A esse respeito, Györg Lukács, no livro História e consciência de classe, identificou que a filosofia clássica alemã era uma etapa do desenvolvimento do pensamento burguês que poderia elevar os problemas ao nível da consciência, mas tem o limite de "[...] ver os problemas concretos da situação histórica e o meio concreto de sair deles." (LUKÁCS, 2003, p. 259).
} 
Por sua vez, a crítica desferida por Marx também se remeteu a uma compreensão do conhecimento que não reconhecia a totalidade das relaçóes, porque priorizava o singular, o fato desvinculado de relaçóes mais amplas e a intuição como meio de apreensão. Um exemplo dessa crítica pode ser reconhecido na Carta a Engels, de 7 de julho de 1866, na qual Marx (1987, p. 34) faz menção a Comte, a quem também combatia: comparado a Hegel, Comte é minúsculo. "Esse desprezível e inútil positivismo apareceu em 1832", assinala. Marx opôs-se a Comte, em virtude de ele compreender o fato pelo fato, sem suas oposições e mediações, tidas como condições fundamentais para entender as relaçóes de produção e de circulaçáo, por exemplo. Também se opôs a ele, devido à concepção linear e progressiva de história, que Marx via com desprezo, dado que o positivismo não pensa a história a partir das contradiçôes sociais e das lutas de classe, mas a partir do progresso científico, enquanto movimento retilíneo e irreversível, que as civilizaçóes alcançariam, com o desenvolvimento de suas instituiçóes e do avanço técnico.

Contudo, se, num primeiro momentum, Althusser ressalta que Marx se ocupou em debater com as filosofias burguesas, no segundo, o autor argelino radicado na França refere-se ao fato de que Marx pretendia "[...] traçar uma linha de demarcação entre os verdadeiros fundamentos teóricos da História e da Filosofia marxista, de uma parte, e das noçóes idealistas pré-marxistas, sobre as quais repousam as interpretaçôes atuais do marxismo como filosofia do homem ou como humanismo, de outra parte." (ALTHUSSER, 1967, p. 7-8).

As implicaçôes dessa passagem em que Marx aprofunda as análises para além do terreno das ideologias e que podem ser vislumbradas nas obras compostas a partir de 1848, em particular, o Capital, levaram Althusser, em $A$ favor de Marx, a situar em níveis diferentes a ciência e a ideologia e, a partir disso, estabelecer o que chamou de "censura epistemológica". Por ela, percebe-se que Marx se dedicou a combater as ideologias, nos primeiros textos e, nos últimos, ocupou-se com os fundamentos teóricos que nortearam todo o seu pensamento. Portanto, o que o Marx da maturidade elaborou foi o que Althusser entendeu como uma descoberta científica sem precedentes, $a$ ciência da história das formaçôes sociais. ${ }^{5}$ Assim como Tales de Mileto abrira ao conhecimento o continente da Matemática e Galileu abrira ao conhecimento

\footnotetext{
${ }^{5}$ Levam-se em consideração os limites do artigo e, por isso, apenas um breve comentário do tema, que exigiria tratamento à parte. A maneira como Althusser interpretou a concepçáo de história, em Marx, também foi objetada por Thompson. No livro A miséria da teoria, ele acusa Althusser de não compreender as categorias essenciais de Marx, a exemplo dos conceitos de classe e de ideologia, além
} 
científico o continente da natureza física, Marx possibilitou ao conhecimento científico um novo aspecto, o da História (ALTHUSSER, 1967).

Segundo Engels, no Discurso diante da sepultura, escrito por ocasião da morte de Marx, em 14 de março de 1883 ([19--a], p. 351), Marx era um homem de ciência, definindo-o como uma força motriz ou revolucionária. Tal como Darwin havia descoberto a lei do desenvolvimento da natureza orgânica, Marx descobrira a lei do desenvolvimento da história humana. Ora, a lei do desenvolvimento da história implica o fato de que o homem precisa primeiro comer, beber, ter um teto e vestir-se, antes de poder fazer política, ciência, arte, religião. Por conseguinte, o ponto de partida para o pensamento consiste no entendimento da produção e da subsequente reprodução da vida real, o que corresponde às etapas do desenvolvimento de um povo.

Grosso modo, o que Marx perscrutou, segundo Engels, foi a articulação entre as forças produtivas como base sob as quais se engendram as relaçóes sociais e as ideias a elas correspondentes, bem como as lutas históricas travadas no interior da mesma sociedade. Ao compreender a história como movimento contraditório e luta de classes, Marx entendeu que cabe à historiografia, única ciência efetiva do homem, a descrição das conexốes reais entre os eventos e não apenas entre as ideias. A verdade deve ser demonstrada na prática histórica, mediante o esforço teórico capaz de sintetizá-la em suas múltiplas determinaçôes. Engels nada fez além de repetir o que já dissera conjuntamente com Marx (2007, p. 93), na Ideologia Alemãa, entre 1845 e 1846, ao afirmar que a observação empírica tem de provar, em cada caso particular, empiricamente e sem nenhum tipo de mistificação, isto é, sem apelar para o idealismo e as filosofias contemplativas (especialmente, a de Feuerbach), a conexão entre a estrutura social e a política e a econômica.

Desse modo, pode-se verificar que, se Marx concebeu a história como movimento contraditório partindo das modificaçóes das bases materiais, ele também possibilitou, segundo Engels, no Discurso de 14 de março de 1883, uma segunda descoberta que seus contemporâneos, alinhados aos princípios burgueses e à esquerda ingênua, ignoravam: a mais-valia. Para Engels ([19-a], p. 351), no Discurso, a mais-valia é tida como uma "[...] lei específica que move o modo de produção capitalista e a sociedade burguesa criada pôr ele." Quando a produção econômica é considerada no conjunto das relaçôes, a análise realizada por Marx e Engels resultava no entendimento de que a

de ter elaborado uma concepção empírica e determinista e, quando muito, estruturalista do pensador do século XIX. 
produção capitalista continha, na forma como estruturava o trabalho e as açóes contidas nele, diferenças existentes entre o valor produzido pela força do operário e o valor pago por essa mesma força.

A partir dessa categoria, a mais-valia, o pensamento de Marx possibilitou o entendimento de um comportamento exploratório do trabalho assalariado. Compreendeu também que as perdas não são apenas econômicas: quando a força de trabalho é expropriada e o trabalhador transformado em apêndice da maquinaria, esvaziam-se as capacidades crítico-criativas. A crítica marxista reside, sobretudo, no modo como o capitalismo transforma tudo em mercadoria, apropriando-se do trabalho alheio e das forças físicas e cognitivas de quem produz. Além disso, ao fragmentar as relaçốes produtivas e, em decorrência, as relaçóes humanas e cognitivas, o materialismo histórico se posiciona contra a fragmentação, na medida em que propóe integrar todos os campos do conhecimento, porque acredita numa realidade com existência objetiva e que poderia ser conhecida pela razão, em contraposição à realidade indeterminada e incognoscível, considerada pela filosofia idealista e pelo objetivismo positivista.

A esse respeito, Lukács (2003, p. 186), o qual desenvolveu extensa reflexão debatendo a formação da consciência de classe, frisa que a insuficiência do idealismo, especialmente do pensamento hegeliano, consistia no fato de ele deixar apenas aparentemente que o espírito absoluto componha de fato a história, o que resultava, grosso modo, na dualidade entre o mundo prático e o teórico. Essa constatação resultava no fato de que a filosofia elaborada por Hegel, segundo Lukács (2012, p. 184), tem por objeto a realidade concebida no seu aspecto lógico-filosófico, motivo pelo qual a razão é, na compreensão de filósofo húngaro, o "[...] princípio último do ser e do devir da natureza e da sociedade." A partir desse aspecto, a tarefa que a filosofia assumiu é a "[...] descobrir e elaborar esse princípio, a fim de que a sociedade corresponda às leis eternas e imutáveis da natureza."

Essa forma abstrata de mundo e da maneira de conhecê-lo, por meio de leis lógicas, não poderia ser assumida por Marx. Distinto do idealismo alemáo de Hegel, não se trata de compreender a realidade como forma pura, mas de partir das bases produtivas da vida, isto é, da atividade material realizada pelo homem, o qual, ao agir, modifica a natureza pelo trabalho. O ser humano age no mundo, transformando-o para satisfazer necessidades objetivas, de modo que o resultado oriundo do trabalho humano constitui um processo histórico. $\mathrm{O}$ caminho, portanto, que leva à possibilidade do conhecimento é a 
descoberta dos processos concretos de desenvolvimento histórico da realidade social, entendida como objeto em permanente construçáo.

Essa concepção da história consiste, portanto, em desenvolver o processo real de produção e partir da produção material da vida imediata e em conceber a forma de intercâmbio conectada a esse modo de produção e por ele engendrada, quer dizer, a sociedade civil em seus diferentes estágios, como o fundamento de toda história. (MARX; ENGELS, 2007, p. 42).

O pressuposto do materialismo dialético radica na demonstração do processo de desenvolvimento histórico das sociedades e, que para os referidos pensadores, as novas formaçóes sociais tendem a substituir suas predecessoras, num movimento revolucionário constante. Assim, as novas sociedades, por sua vez, criam as condiçóes materiais e ideológicas para a sua legitimação, mas também para a sua suplantação ou superação. Nesse caso, Marx assinala que a história é um movimento constante, mas que não acontece apenas no pensamento, a exemplo da dialética hegeliana. O movimento éo antagonismo de classes, das relaçôes materiais de existência e, desse modo, do esgotamento das forças produtivas geradas pelas contradiçóes internas. A força que póe a história em movimento não está no pensamento, mas nas condiçôes produtivas de existência que motivam a compreensão teórica dessas relações (HOBSBAWM, 1998).

Por conseguinte, a base material e terrena da vida e sua modificaçáo é que foi transformada no objeto fundamental do pensamento de Marx e Engels e, por extensão, do conhecimento e da ciência. Para Marx, o objeto é o mundo objetivo e as mediaçốes possibilitadas pelas açôes humanas. De acordo com Gyorgy Markus (1974), o processo pelo qual a atividade humana se torna mediatizada tem como consequência (e como pressuposto) que seja liquidada a confusão entre o sujeito e objeto. O objeto, o mundo objetivo, aparece como uma realidade estável, independente da relação momentânea que o homem eventualmente estabelece com ele. Quanto ao sujeito, partese do pressuposto de que ele é um ser histórico e social capaz de humanizar a Natureza e, como tal, pode desenvolver e aperfeiçoar a sua consciência. $\mathrm{O}$ sujeito está, pois, inserido na vida material e concreta que constitui, por sua vez, o objeto do conhecimento.

Nesse sentido, Markus (1974) sublinha que, em Marx, a consciência tem sua origem na natureza social do homem e ela existe somente enquanto consciência condicionada e posta em existência pela sociedade. A consciência 
é, portanto, em todas as suas formas, uma atividade voltada para a apropriação da Natureza. É nesse caso que se pode vislumbrar a existência de uma reflexão direcionada para o problema do conhecimento, em Marx. Nas páginas dos Manuscritos Econômicos e Filosóficos ou Manuscritos de Paris, de 1848, o autor afirma:

[...] minha consciência universal é apenas a figura teórica daquilo de que a coletividade real, o ser social, é a figura viva, ao passo que hoje em dia consciência universal é uma abstração da vida efetiva e como tal se defronta hostilmente a ela. Por isso, também a atividade da minha consciência universal - enquanto uma tal [atividade] - é minha existência teórica enquanto ser social. (MARX, 2010, p. 107).

O que Marx parece assinalar é o fato de que nossa consciência não está determinada a priori, mas entrelaçada com os acontecimentos e as atividades materiais desempenhados pelos homens. Descobrir os mecanismos dessa articulação já é um ato de conhecer, uma vez que a teoria, no sentido da ação dialética, é capaz de compreender as relaçôes da vida prática, anunciar a essência mesma dessa prática e reconhecer suas nuances e diferenças. Desvela, por exemplo, que a consciência e a atividade humana são diferentes, porém, ao mesmo tempo vinculadas em uma unidade mútua: pensar e ser são diferentes, mas apresentam coesão recíproca (MARX, 2010). Dessa maneira, de acordo com Marx, primeiro o homem existe, produz, trabalha, para depois representar o mundo. A produção das ideias, as representaçóes estáo entrelaçadas com a atividade material e o intercâmbio dos homens. $\mathrm{O}$ representar, o pensar e a interação espiritual dos homens, como afirmam os autores da Ideologia alemã, aparecem como resultado direto do comportamento material (MARX; ENGELS, 2007).

[...] [é preciso] explicar a práxis partindo da ideia, mas de explicar as formaçóes ideais a partir da práxis material e chegar, com isso, ao resultado de que todas as formas e [todos os] produtos da consciência náo podem ser dissolvidos por obra da crítica espiritual, por sua dissolução na "autoconsciência" ou sua transformaçáo em "fantasma", "espectro", "visôes" etc., mas apenas pela demolição prática das relaçōes sociais reais de onde provêm essas enganaçóes idealistas. (MARX; ENGELS, 2007, p. 43).

Desse modo, o conhecimento pressupóe que o homem deva existir como sujeito real, que aprenda a ver, a sentir, isto é, a captar o mundo sensível 
e abstrair suas conexôes. Em seguida, na forma da linguagem humana, da universalidade da consciência, tal como se fixou na linguagem, o homem deve dar uma articulação estável aos fenômenos, de acordo com a própria estrutura que é dada - de uma forma inteiramente independente do homem - na linguagem, isto é, na consciência social materializada. Ao homem cabe se apropriar do mundo não apenas em sua atividade material, mas também em sua atividade espiritual. A estrutura na qual os objetos estão articulados não é arbitrária, porque a natureza dos objetos e de nossos órgáos sensoriais the impóe limites (MARKUS, 1974).

Essa posição difere, como se pode observar, do positivismo e do pensamento hegeliano, porque o que Marx elaborou foi uma nova atividade teórica, a qual parte da prática ${ }^{6}$ constituída para entender as relaçóes humanas contidas nela. As relaçôes humanas implicam, segundo Caio Prado Júnior (2002), a maneira como as feiçôes e situaçóes da realidade exterior ao pensamento conhecedor, que constitui o objeto do conhecimento, se dispóem e se compóem, em si e entre si, no espaço e no tempo. Quer dizer, o pensamento trata de apreender e representar mentalmente a disposição respectiva na simultaneidade e na sucessão das relaçóes presentes na realidade e nelas incluídas.

Ora, isso significa que os objetos do conhecimento estáo sempre relacionados numa totalidade e também em uma nova unidade, quando as relaçôes são apreendidas pelo pensamento, tal como Marx havia referido na Introdução à Contribuição à Crítica da Economia Política, de 1857. Nela, ao discutir o modo como a economia política procede na análise dos problemas, Marx afirma que os objetos do conhecimento aparecem no pensamento como processo de síntese das determinaçóes (unidade do diverso) do concreto e não como causa dele. $\mathrm{O}$ pensamento e o conhecimento não são, portanto, causas das determinaçóes materiais, mas, inversamente, são a reprodução conceitual daquilo que foi apreendido do concreto. É o concreto pensado. Como objeto, a coisa pensada pelo sujeito real é material e, sem o comportamento teórico que o investiga, não se reconhecem suas articulações. Como resultado da apreensão, o conhecimento é transformado em categorias de análise, as

\footnotetext{
${ }^{6}$ No âmbito do materialismo dialético, a prática consiste em uma correspondência essencialmente histórica, universal, náo possuindo uma correspondência automática e imediata com a atividade particular de um dado indivíduo. A prática humana, a qual inclui a produção do conhecimento, encerra sempre a relaçáo entre o singular particular e o universal, sendo um fenômeno histórico, posto que as propriedades humanas subjetivas e objetivas que a comportam resultam de amplas e complexas relaçôes do homem com a Natureza (ABRANTES; MARTINS, 2007).
} 
quais reproduzem conceitualmente as relações concretas. É a partir do reconhecimento das relaçóes pertencentes a uma realidade que o sujeito elabora conceitos que representam as diversas modalidades ou componentes dessa realidade desvelada, num todo articulado. Dessa maneira, o "[...] todo, tal como aparece no cérebro, como um todo mental, é um produto do cérebro pensante, que se apropria do mundo da única maneira em que pode fazer, maneira que difere do modo artístico, religioso e prático de se apropriar dele." (MARX, 2008, p. 259-260).

Considera-se, por fim, que as categorias de pensamento, na medida em que explicitam relaçóes concretas, podem ser reconhecidas historicamente, embora as categorias possam assumir sentidos diversos, porque exprimem modos de ser, de existir etc. de um tempo histórico. O conhecimento supóe, assim, o reconhecimento do caráter histórico do homem e de sua ação, de suas atividades. Marx enfatiza, por exemplo, o papel do trabalho no processo cognitivo e, por conseguinte, no caráter social, irredutivelmente histórico, de seu produto: o conhecimento. Isso sugere que o trabalho colabora, porque, enquanto ação, é parte das mediaçóes intencionais realizadas pelos indivíduos, a práxis, enquanto atividade criativa por meio do qual o mundo é produzido e transformado (BOTTOMORE, 2001).

Dessa forma, o conhecimento é universal, na medida em que a atividade do homem também tem esse caráter dinâmico, e a ciência (expressão particular do conhecimento), por sua vez, produz os meios e métodos para a apropriaçáo espiritual do real, tendendo a tornar-se um organismo autônomo dotado de leis próprias. Segundo a interpretação de Markus, a atividade científica pensada por Marx surge como ramo da divisão social do trabalho e, com ela, a própria ciência enquanto produto universal do desenvolvimento humano (MARKUS, 1974).

Com efeito, no Capital, obra de maturidade, Marx, ao analisar a transição da manufatura para a maquinofatura, observa uma modificação no modo de ser e na transformação da ciência e do conhecimento. Na manufatura, fundada na cooperação simples, o trabalho ainda era concreto e seus elementos tinham um caráter teórico-prático, por meio do qual o trabalhador experienciava uma relação mais criativa e autônoma. Na maquinofatura, por sua vez, acentua-se a divisão do trabalho e, com ele, especificam-se os instrumentos de trabalho e as habilidades cognitivas, que perdem o referencial do todo. $\mathrm{O}$ sujeito perde o contato físico com o objeto, ficando mais distante de efetivar a experiência formativa. Assim, como as condiçóes materiais e as necessidades que se póem 
no processo de produção engendram o conhecimento, estes passam a estar atrelados aos novos inventos, os quais servirão à indústria e não ao homem.

Contudo, se à primeira vista está claro que a grande indústria tem de incrementar extraordinariamente a força produtiva do trabalho por meio da incorporação de enormes forças naturais e das ciências da natureza ao processo de produção, ainda não está de modo algum claro, por outro lado, que essa força produtiva ampliada náo seja obtida mediante um dispêndio aumentado de trabalho. (MARX, 2013, p. 460).

De fato, no capítulo XIII da quarta seção do Livro I do Capital, Marx menciona a apropriação da ciência para fins práticos, utilitários, que serve ao capital e não às necessidades humanas. Ele assevera que há um controle da ciência tanto quanto há do capital. Quem controla o capital controla também a produçáo do conhecimento, já que ele se alinha aos fatores produtivos, o que também incide na formação humana e na definição do elenco de novas habilidades. Um dos aspectos relativos à formação, abordado por Marx (2013), diz respeito às consequências da industrialização sobre a formação do homem. Entre as considerações, consta o fato de que a maquinaria não dispensa a força física, todavia, mais do que a força física, precisa de um homem resignado. Para resigná-lo, é preciso retirar o capital intelectual, pelo modo como a produçáo se organiza e pela educação que recebe, a qual separa a atividade material da intelectual. Sugere, por consequência, a transformação da educação, que se define a partir do tecnicismo. Para trabalhar nas máquinas, o trabalhador tem de começar sua aprendizagem muito cedo, a fim de adaptar seu próprio movimento ao movimento uniforme e contínuo de um autômato, conforme o autor destaca, no Capital (MARX, 2013).

O que sucede com as forças da natureza sucede igualmente com a ciência. Uma vez descobertas, a lei que regula a variação da agulha magnética no campo de ação de uma corrente elétrica ou a lei da indução do magnetismo no ferro, em torno do qual circula uma corrente elétrica, já não custam mis um só centavo. Mas, para que essas leis sejam exploradas pela telegrafia etc., faz-se necessária uma aparelhagem muito custosa e extensa. Como vimos, a ferramenta náo é eliminada pela máquina. De uma ferramenta limitada do organismo humano, ela se transforma, em dimensão e número, na de um mecanismo criado pelo homem. Em vez de uma ferramenta manual, agora o capital póe o trabalhador para operar uma máquina que maneja por si mesma suas próprias ferramentas. Contudo, se à primeira vista está claro que a grande indústria tem de incrementar extraordinariamente a força produtiva do trabalho por meio da incorporação de enormes forças 
naturais e das ciências da natureza ao processo de produção, ainda não está de modo algum claro, por outro lado, que essa força produtiva ampliada não seja obtida mediante um dispêndio de aumentado de trabalho. Como qualquer outro componente do capital constante, a maquinaria náo cria valor nenhum, mas transfere seu próprio valor ao produto, para cuja produção ela serve. $\mathrm{Na}$ medida em que tem valor e, por isso, transfere valor ao produto, ela se constitui num componente deste último. Ao invés de barateá-lo, ela o encarece na proporção de seu próprio valor. E é evidente que a máquina e a maquinaria sistematicamente desenvolvidas, o meio de trabalho característico da grande indústria, contêm desproporcionalmente mais valor do que os meios de trabalho da empresa artesanal e manufatureira. (MARX, 2013, p. 460).

Dessa maneira, ele assevera que, assim como na divisão do trabalho, o capitalismo também dividiu e fragmentou o conhecimento. Sob essa perspectiva, aos operários não cabe a ciência (o domínio teórico), uma vez que ela é apropriada para cumprir as funçóes produtivas. Por outro lado, ela, como produto das relaçóes históricas, é condição necessária para captar o movimento do real; porém, a subordinação dela aos interesses do capital converte-se em ideologia e alienação. Tal condição neutraliza as potencialidades da ciência com vistas à emancipação do homem com relação às forças produtivas. Esse aspecto pode ser compreendido a partir da análise realizada por Engels, no livro a Introdução da Dialética da Natureza (s/d), por meio do qual ele considera o desenvolvimento das ciências modernas. A ciência, em suas origens, libertou o homem dos mitos e das crenças e, por isso, as mudanças sociais não podem ser pensadas sem o entendimento das contradiçóes da ordem econômica. Por meio dela, o homem alcançaria o direito à existência. Trata-se, então, de fazer o mesmo na ordem econômica e social - transformar suas bases para transformar as bases do conhecimento.

No caso particular de Horkheimer, um dos membros fundadores da Escola de Frankfurt, esse crítico do século XX afirmou que a ciência, na teoria da sociedade sustentada por Marx, figura entre as forças produtivas do homem. Ela tornou possível o sistema industrial moderno, como condição do caráter dinâmico do pensamento, o qual, nos últimos séculos, se desenvolveu com ela e possibilitou conhecimentos que contribuíram para determinar, de forma decisiva, a vida social. Na medida em que a ciência existe como meio para a produção de valores sociais, quer dizer, formulada segundo métodos de produção, ela também tem o papel de meio 
de produção e, como tal, serve igualmente aos propósitos da emancipação humana (HORKHEIMER, 2003).

Assim, a importância das obras de Engels e Marx teve alcance universal, dados os inúmeros estudos, nem todos eles concordantes entre si, que abordam os diversos aspectos de uma produção teórica a qual pretende abarcar o conhecimento como expressão da totalidade do real em suas diferentes formações sociais. Entre as contribuiçôes mais originais desses pensadores, embora seus críticos menos tolerantes possam discordar, está a descoberta dos mecanismos de funcionamento da produçáo capitalista e da ordem social burguesa. $\mathrm{O}$ que torna valorosa essa discussão reside no fato de que permite compreender os procedimentos que explicitam a constituição histórico-social do objeto de pensamento, o conjunto de funcionamento do capitalismo e sua lógica produtiva. É a partir desse propósito que os estudos sobre a ciência e o conhecimento devem ser considerados, já que oferecem um modelo de conhecimento capaz de desmitificar a deificação do mercado.

\section{CONSIDERAÇÓES FINAIS}

Este ensaio buscou tratar da perspectiva adotada por Marx e Engels, a respeito do conhecimento ou ciência. Marx considerou que o conhecimento até então formulado permitiu colocar em evidência aspectos da realidade ancorados nos limites das categorias lógicas. Entendia que o pensamento burguês, materializado especialmente no idealismo, teria dado significativas contribuiçôes, porque ofereceu recursos que permitiam o desenvolvimento das ciências, mas continha limites: não compreendia o fato de o conhecimento e de a ciência estarem vinculados às contraditórias relaçóes sociais e produtivas.

Desse modo, ao rejeitarem o idealismo filosófico e a interpretação burguesa da economia política, Marx e Engels estabeleceram novos fundamentos para as ciências sociais e humanas. Para eles, o conhecimento é sempre o da totalidade da sociedade, enquanto resultado das atividades concretas desempenhadas pelo ser humano. É exatamente esse o caráter original do marxismo: repensar a sociedade capitalista, todavia, não na perspectiva burguesa, o que significa repensar os fundamentos do conhecimento. Para o entendimento das relaçóes sociais, Marx e Engels examinaram a produçáo material da vida, procurando estabelecer as conexốes entre o econômico e o político, entre a sociedade e a consciência de classes, as ideologias etc. Em outras palavras, destacaram a interaçáo do desenvolvimento social e, por 
isso, eles continuam essenciais para os que se aventuram a estudar as ciências humanas e sociais.

Marx, ao atribuir às ciências a condição de crítica social, rompeu com as posturas místicas e benfazejas que acreditavam que a terra deveria prestar reverência ao céu, projetando-se para além do mundo. Estabeleceu a crítica aos que pensavam o conhecimento fundado em categorias abstratas, as quais não explicitavam as relaçôes práticas, para situá-lo na objetividade, isto é, nas práticas humanas que vinculam o homem e a natureza por meio do trabalho. Dessa maneira, o objeto do pensamento ou da ciência foi compreendido como produto histórico da ação humana e não da contemplação, perspectiva que mostra a dimensão social das ideias.

A esse respeito, também é preciso considerar que a ciência social por eles elaborada tinha como perspectiva combater as ideologias convertidas em religiáo e culto a Zeus (o capital) ou em dado inexorável da Natureza, como pretendia o liberalismo, e conceber a história em seus movimentos de transformação, a fim de intervir, tanto quanto possível, na mudança da sociedade, sobretudo em favor daqueles que são vítimas do próprio processo de luta histórica. Em suma, a originalidade desses pensadores consiste no fato de subordinar a ciência aos propósitos emancipatórios de uma classe social específica, a de proletários, condição que exigia o aprimoramento da capacidade teórica de conhecer a realidade que se pretendia transformar. $\mathrm{O}$ conhecimento e a ciência social que defendiam eram, por fim, instrumentos que garantiriam ao homem o entendimento das relaçôes desse mundo e, por isso, ferramenta indispensável para iluminar momentos turbulentos como o nosso.

BORDIN, Reginaldo Aliçandro. The historical-social character of knowledge in Marx's thought. Tans/form/ação, Marília, v. 40, n. 3, p. 157-174, Jul./Set., 2017.

\footnotetext{
Abstract: This text aims to discuss the theory of knowledge in Marx and Engels, noting as well their studies of science. These two thinkers of the nineteenth century did not stand out for developing philosophical reflections on the subject, in contrast to the moderns. In order to understand their own historical moment, characterized by capitalist production, Marx and Engels concerned themselves with criticizing and revising the idealist philosophies of their day, considering these philosophies to be ideological and insufficient for thinking about what they understood by material and social reality. They therefore developed new theoretical assumptions which sought to clarify the relationship between productive forces, understanding these forces as the basis upon which social relations and the ideas corresponding to them, as well as the historical struggles within society, were engendered. They
} 
understood that knowledge and science are articulated on the basis of material production, and saw it as their task to explain the relationship between these factors. This way of understanding the society of their time was an original one, justifying studies that seek theoretical references in their thought that are useful for understanding current contradictions.

Keywords: Science. Knowledge. Marxism.

\section{REFERÊNCIAS}

ABRANTES, A. A.; MARTINS. L. M. A produção do conhecimento científico: relação sujeito-objeto no desenvolvimento do pensamento. Interface - Comunic., Saúde, Educ., v. 11, n. 22, p. 313-25, maio/ago. 2007.

ALTHUSSER, L. A favor de Marx. 2. ed. Rio de Janeiro: Jorge Zahar, 1967.

BOTTOMORE, T. (Org.). Dicionário do pensamento marxista. Rio de Janeiro: Jorge Zahar, 2001.

ENGELS, F. Discurso diante da sepultura de Marx. In: MARX, K.; ENGELS, F. Obras escolhidas. São Paulo: Alfa-Omega, [19--a]. V. 2. p. 349-352.

. Introdução à dialética da natureza. In: MARX, K.; ENGELS, F. Obras escolhidas. São Paulo: Alfa-Omega, [19--b]. V. 2. p. 249-266.

. Carta a Konrad Schmidt, de 27 de outubro de 1890. In: MARX, K.; ENGELS,

F. Cartas filosóficas e o manifesto do partido comunistas de 1848. São Paulo: Moraes, 1987. p. $43-48$.

HINKELAMERT, F. Hacia una critica de la razón mítica: el labirinto de la modernidad. San José: Alerkin, 2007.

HOBSBAWM, E. Sobre história. São Paulo: Companhia das Letras, 1998.

HORKHEIMER, M. Teoría critica. Buenos Aires: Amorrortu, 2003.

LUKÁCS, G. História e consciência de classe: estudos sobre a dialética marxista. São Paulo: Martins Fontes, 2003.

Para uma ontologia do ser social. São Paulo: Boitempo, 2012, vol. I.

MARKUS, G. Teoria do conhecimento no Jovem Marx. Rio de Janeiro: Paz e Terra, 1974.

MARX, K. Teses sobre Feuerbach. In: MARX, K.; ENGELS, F. A ideologia alemã: seguida das Teses sobre Feuerbach. São Paulo: Moraes, 1984. p. 107-111.Cap. 1.

. Carta a Engels, de 7 de julho de 1866. In: MARX, K.; ENGELS, F. Cartas filosóficas e o manifesto do partido comunistas de 1848. São Paulo: Moraes, 1987. p. 33-34.

. Diferencia entre la filosofia de la naturaleza de Demócrito y Epicuro. México: Fondo de Cultura Económica, 2004. 
Introdução à contribuição à crítica da economia política. In: MARX, K. Contribuição à crítica da economia política. 2. ed. São Paulo: Expressão Popular, 2008. p. $237-272$.

. Manuscritos econômico-filosóficos. São Paulo: Boitempo, 2010.

. O capital: crítica da economia política: Livro I. São Paulo: Boitempo, 2013.

. Carta de Marx a Engels em 07 de Dezembro de 1867. In: MARTINS, M. V.; MEDEIROS, J. L. Apresentação da Carta de Marx a Engels em 07 de Dezembro de 1867. NiepMax, Rio de Janeiro, v. 2, n. 2, p. 207-213, 2014. Disponível em: http://www. marxeomarxismo.uff.br/index.php/MM/article/view/49/38. Acesso em: 15 jan. 2016.

MARX, K.; ENGELS, F. Obras escolhidas. São Paulo: Abril Cultural, 1978 (Os Pensadores).

. A ideologia alemã. São Paulo: Boitempo, 2007.

PAULO NETTO, J. Introdução à obra de Marx. Disponível em: http://marxismo21. org/wp-content/uploads/2012/07/Introduc\%C3\%A3o-\%C3\%A0-obra-de-MarxŁos\%C3\%A9-Paulo-Neto.pdf. Acesso em: 05 jan. 2016.

PRADO JÚNIOR, C. Teoria marxista do conhecimento e método dialético materialista. São Paulo: Ridendo Castigat Mores, 2001.

THOMPSON, E. P. A miséria da teoria ou um planetário de erros: uma crítica ao pensamento de Althusser. Rio de Janeiro: Zahar, 1981.

Recebido em 02/05/2016

Aceito em 26/09/2016 